\title{
The Reel (Re)Presentation of the Artist in Late Twentieth Century American Film
}

\author{
By Dena Gilby*
}

\begin{abstract}
Throughout the twentieth century, American films were not only a potent site of reflection, contention, provocation and contemplation of social, political, and religious mores, but also of the search for identity in the world. There were, additionally, a number of films that attempted to outline the character of the artist. Some romanticized the artist's life-one can think of Donald Sutherland's portrayal of Paul Gauguin as an almost tragic hero in A Wolf at the Door (1987), or the doomed anti-hero of Jeffrey Wright's Basquiat (1996). Others, such as Legal Eagles (1986) and I Shot Andy Warhol (1996), recreated the milieu of the art world, especially that of New York City. This presentation provides a comparison of $A$ Wolf at the Door to Basquiat and Legal Eagles to I Shot Andy Warhol to reveal a deep-seated set of notions about artists and art, Modernism and Postmodernism to which the film industry of the last years of the twentieth century may be viewed as a response. The films capture traditional American views not only on the nature of the artist, but also larger issues; indeed, these films purportedly present to the viewer insights into the origins and manifestations of human creativity.
\end{abstract}

\section{Introduction}

Throughout the twentieth century, American films were a potent site of reflection, contention, provocation, and contemplation of social, political, and religious mores, of the search for identity in the world. ${ }^{1}$ There were, additionally, a number of films that attempted to outline the character of the artist. Some romanticized the artist's life-one can think of Donald Sutherland's portrayal of Paul Gauguin as an almost tragic hero in Oviri (A Wolf at the Door) (1987), or the doomed anti-hero of Jeffrey Wright's limning of the titular character of Basquiat (1996). Others, such as Legal Eagles (1986) and I Shot Andy Warhol (1996), recreated the milieu of the art world, especially that of New York City. Legal Eagles and I Shot Andy Warhol treat a limited period of time in order to examine the "microhistory" of the art world of the late 1960s in New York. Arguably, however, the subtext of these films is not a particular location at a specific time, but the character of the artist throughout time and a simplified version of the nature/nurture debate. This paper provides a comparison of Oviri to Basquiat and Legal Eagles to I Shot Andy

*Professor, Endicott College, USA.

1. For an exploration of the "social-ideological value of film" see Richard Dyer, "Introduction to Film Studies," in Film Studies: Critical Approaches, ed. John Hill, and Pamela Church Gibson (Oxford and NY: Oxford University, 2000), 4-8. 
Warhol to reveal a deep-seated set of notions about artists and art, Modernism and Postmodernism to which the film industry of the last years of the twentieth century responded. ${ }^{2}$ This reaction seems to encapsulate American views not only on the nature of the artist, but also larger issues; these films purportedly present to the viewer insights into the origins and manifestations of human creativity.

It is not the purpose of this paper to parse the historical accuracy and inaccuracy in the filmic texts. While this is a useful and enlightening exercise and pertinent details will be pointed out, it will not ultimately bring the viewer closer to understanding the representation and reception of the celluloid construction of the artist. What such an enterprise can do is delineate the historical conditions of an artist in his/her time by highlighting where films fail to capture historical specificities. Moreover, this paper is not concerned with the aesthetic elements of these productions. This facet is too immense to be handled in this venue; instances in which the aesthetics help to construct the artist's character, note will be taken. Finally, it is not the author's intention to denigrate the medium of film; only the mis(sed)representations about artists that seem to dominate American Hollywood cinema at the end of one century and beginning of another; rather, the point of departure in this essay is the idea of representation: that film both reflects and defines the object of representation. Moreover, the image, itself, has been sieved through many layers, both culturally and societally specific and individually perceived. The artist as subject, in this way, seems an apt canvas for the American filmmaker. He or she is able to encapsulate myriad notions about creativity, art, the art world, as well as to explore what many believe to be a uniqueness in the artistic individual through providing a few broad strokes on the artists' character. Related issues include the following: what do audiences really believe about artists? What do they derive from viewing an artist's life on film and is "truth" what they are after? Do they identify with the artist? Do they wish to be the artist? Ultimately, these issues rest on "the "theory of identification," that is outlined by Christian Metz, in which viewers are seen to identify primarily with the camera and secondarily with a character. ${ }^{3}$ Thus, in these films, the secondary identification will be with the artist, causing the viewer to sympathize or empathize with his/her circumstances. Of concern, too, are the psychoanalytical theories that Laura Mulvey proved to be so seminal to film images. Through theories of the gaze that Mulvey parses, the artist becomes the viewed upon which the viewer can play out their own fantasies of genius and creativity without the sting of rejection.

2. David Bordwell and Noël Carroll, (eds.), Post-theory: Reconstructing Film Studies (Madison, WI: University of Wisconsin, 1996); Natalie Zemon Davis, Slaves on Screen (Cambridge, MA: Harvard University, 2000); Robert Rosenstone, Visions of the Past: The Challenge of Film to Our Idea of History (Cambridge, MA: Harvard University Press, 1996).

3. Christian Metz, The Imaginary Signifier: Psychoanalysis and the Cinema (Bloomington, IN: Indiana University Press, 1986). 


\section{Literature Review}

The literature on the depiction of artists in mainstream films; that is, not documentaries but studio and independently produced biopics, demonstrates a consensus that these films are less about the facts of an artist's life and more about capturing the personality of the artist. ${ }^{4}$ Some address that, because of the medium, feature films often focus on a limited story - even if the themes are quite lofty or complex - in order to examine the "microhistory" of the art world. Arguably, however, the subtext of these films is not a particular location at a specific time, but the character of the artist throughout time and a simplified version of the nature/nurture debate. ${ }^{5}$ Additionally, a number of authors focus on the fact that artists' biopics more often than not construct the personality along several stereotypes, the most compelling of which to filmmakers (according to a majority of the critical texts) is the myth of the artist-genius, as well as the idea that creativity comes from mental anguish. ${ }^{6}$ Finally, a few authors emphasize how the art world is the emphasis of the film rather than the artist him/herself. ${ }^{7}$

4. Carolyn Anderson and Jonathon Lup, “Off-Hollywood Lives: Irony and Its Discontents in the Contemporary Biopic," Journal of Popular Film and Television 36, no. 2 (Summer 2008): 102-112; Bernard Beck, "Real Genius: Pollock and Portraits of Artists in Movies," Multicultural Perspectives 3, no. 4 (2001): 11 -14; Doris Berger, Projected Art History: Biopics, Celebrity Culture, and the Popularizing of American Art (NY and London: Bloomsbury, 2014); Anne Billson, "The Art of Film: Galleries in the Movies," The Telegraph, posted January 9, 2015, accessed May 23, 2020, https:/goo.gl/NYi31M; David Bovey, "The Artist Biopic: A Historical Analysis of Narrative Cinema, 1934-2010" (PhD. diss., University of Westminster, 2015); Steven Jacobs, Framing Pictures: Film and the Visual Arts (Edinburgh: Edinburgh University Press, 2011); Jim Leach, "A Matter of Life and Art: Artist Biopics in Post-Thatcher Britain," in Rule, Britannia! The Biopic and British National Identity, ed. Homer B. Pettey, and R. Barton Palmer (Albany: State University of New York Press, 2018), 163181; Bronwyn Polaschek, The Postfeminist Artist Biopic (London: Palgrave Macmillan, 2013); Belen Vidal, "Feminist Historiographies and the Woman Artist's Biopic: The Case of Artemisia," Oxford Journal 48, no. 1 (2007): 69-90.

5. Natalie Zemon Davis, Slaves on Screen (Cambridge, MA: Harvard University Press, 2000), 6; Bovey, 2015; Leach, 2018.

6. Beck, "Real Genius," 11-14; Laura R. Grasso, "Misery, Then Tragedy: The Rise and Fall of an Artist's Myth in Relationship to the Culture Industry" (Master's Thesis, Sotheby's Institute of Art, 2015); Rivka D. Mayer, "Transformations of Cinematic Signifiers of the Myth of Genius," Master's Thesis (University of Liverpool, 2001).

7. Billson, 2015; Berger, 2014; Angela Dalle Vacche, Cinema and Painting: How Art is Used in Film (Austin: University of Texas Press, 1996); Jim Gaylord, "10 Things Hollywood Teaches Us About the Art World," Art in the Movies, posted December 24, 2014, accessed May 23, 2020, https://goo.gl/XzKPfX; Steven Jacobs, "Strange Exhibitions: Museums and Art Galleries in Film," in Strange Spaces: Explorations into Mediated Obscurity, ed. André Jansson, and Amanda Lagerkvist (Burlington, VT: Ashgate, 2009), 297-316; Peter Plagens, “Biopics Mix Shticks, Kitsch," ARTnews 105, issue 11 (December 2006): 118-121. 


\section{Methodology}

This essay uses cultural analysis to parse the films' intended and subconscious levels of meaning. ${ }^{8}$ Such an analysis of the cultural, ideological, and political messaging implicit in the various products offers insight into the ways that these films both reveal and construct stereotypes about artists and the nature of the creative life. ${ }^{9}$

\section{Plot Summaries}

As an aid to gleaning the film-going public's conceptions of the artist, fostered by filmmakers (and perhaps even created by them), a mapping of the plots of these films is necessary. A cartography of the narrative line clearly demonstrates how academic discourses on Modernism and Postmodernism filter into how filmmakers conceive and present concepts of the nature of the artist's life and creativity. ${ }^{10}$ Oviri chronicles the years 1893-1895 in the life of Paul Gauguin. He has returned from his first sojourn in Tahiti (1891-92) and is desperate to return to the South Pacific. ${ }^{11}$ The film focuses on Gauguin's efforts to secure the funds to do so, while simultaneously exploring the roots of his creativity through his relationships, especially with women. Basquiat, like Legal Eagles, treats the 1980s New York art scene. However, the focus is on a single artist and the film reads like a monograph of an artist's life and oeuvre. ${ }^{12}$

After a young woman, Chelsea Dearden, is caught attempting to steal a painting, the New York City Assistant District Attorney (played by Robert

8 Karen Gocsik, Dave Monahan, and Richard Barsam, Writing About Movies, fifth edition (NY: W.W. Norton \& Company, 2019), 55-57.

9. Gocsik, Monahan, and Barsam, Ibid. As a trained art historian, I also draw on the new art history in which art is examined as intimately connected to the society in which it is created. See, Anne D'Alleva, Look! Again: Art History and Critical Theory (Upper Saddle River, NJ: Pearson, 2005), 72-76; Jonathan Harris, The New Art History: A Critical Introduction (London and NY: Routledge, 2001), 1-34.

10. Peter Brunette, "Post-structuralism and Deconstruction," in Film Studies: Critical Approaches, ed. John Hill and Pamela Church Gibson (Oxford and NY: Oxford University, 2000), 89-93.

11. Françoise Cachin, Gauguin: The Quest for Paradise (NY: Harry N. Abrams, 1992); Gabriele Crepaldi, Gauguin: A Restless and Visionary Genius-His Life in Paintings (NY: Dorling Kindersley, 1999); Stephen Eisenman, Gauguin's Skirt (London: Thames and Hudson, 1997).

12. Jean-Michel Basquiat, Basquiat (Milan: Charta, 1999); Phoebe Hoban, Basquiat: A Quick Killing in Art (NY: Penguin, 1997), Richard Marshall et al., Jean-Michel Basquiat (NY: Abrams, 1995); Glenn O’Brien, Basquiat (NY: Tony Shafrazi Gallery, 1999). 
Redford) and a young, independent defense attorney (played by Debra Winger) are drawn into the New York art world in search of the truth about the "theft" in Legal Eagles. What they uncover is a web of fraud and homicide stretching back almost twenty years, from 1986 to 1968. I Shot Andy Warhol similarly follows a single female character, Valerie Solanas, as she circles the ultra-hip art milieu of Andy Warhol from the fall of 1966 through the spring of 1968, at which point she shoots Warhol and is incarcerated in a mental institution. ${ }^{13}$

\section{Artist Stereotypes: The Modernist/Postmodernist Divide}

The artist in films that are essentially biopics is usually presented in what may be called a truly Modernist idiom: misunderstood, anti-bourgeois, suffering, genius. In Oviri, for instance, Gauguin is limned at the Durand-Ruel Gallery showing of his misunderstood Tahitian works. In this venue he endures the coarse comments of the uncomprehending masses, and the film viewer is introduced to the concept of the wolf. ${ }^{14}$ The title of the film, furthermore, acts as a summary statement. Gauguin is the wolf at the door of late nineteenth century Parisian salon society. ${ }^{15}$ As the creature who would rather die than exist in captivity, he cannot allow himself to be fettered by the constricting chains of bourgeois domesticity. One scene in particular demonstrates this contention. It is the scene of Gauguin with his wife and a coterie of respectable Danish couples riding in a haywain. Gauguin is trussed up in a "monkey suit," his hair slicked down unnaturally. Suddenly, he leaps from the vehicle, tears off the offensive clothing and escapes down the road to freedom, shocking the imprisoned (unaware of their chains) passengers.

Part of Modernism's creed is that the artist lives innately, is not tamed-

13. For an instructive example of what the Factory was like, confer with the photographs of Billy Name, All Tomorrow's Parties: Billy Name's Photographs of Andy Warhol's Factory (NY: Powerhouse Cultural Entertainment, 1997). Additionally, Matthew Collings offers up pithy tales about the scene, one of which is this interesting insight on Solanas: "She ended her days in a welfare hotel, dying alone in the 80s sometime. Her book The SCUM Manifesto is fantastically well written with an intelligent condensed style and sharp humour [sic]. Although shooting people is bad, it's an injustice that history doesn't recall how good a writer she was [. . .] " (It Hurts: New York Art from Warhol to Now [London: 21 Publishing, 1998]), 14.

14. In a letter to the critic André Fontainas, Gauguin recounts the tale about the wolf. He states that Degas, at the Durand Ruel show of November 1893, described a fable by La Fontaine as apt to Gauguin's character. The wolf, according to the tale, would rather starve than be placed in a collar and pampered, for then the wolf is not free. Cachin, Gauguin, 146 reproduces the letter.

15. John Milner, The Studios of Paris: The Capitol of Art in the Late Nineteenth Century (New Haven and London: Yale University Press, 1990). 
and therefore stripped of his/her natural abilities. Basquiat is limned as such a wild child, the product of the streets, and a "natural" artist untouched by the pretentious, overly educated, no talent masses. ${ }^{16}$ The viewer's first glimpse of him, in fact, is when he emerges from a cardboard box in which he has obviously slept. Hence, in both Oviri and Basquiat, the artist is someone who is untrained or innately genius; this genius causes him to be misunderstood and to suffer, for it is in true suffering that art emerges. This idea is perpetuated in Jeffrey Wright's performance: Basquiat is a man whose abilities transcend verbal articulation; while he cannot speak a sentence without stuttering, repeating or pausing in odd places, he can and does paint creative verve onto the canvas. In these two films both Gauguin and Basquiat are, in many ways, misfits. Gauguin, though admired by his compatriots, is not understood by mainstream French society of the era; within his peer group, he is not a shocking and provocative figure; he is the dominant figure, the man to whose genius everyone defers. While this may seem an enviable position, none of his colleagues have the courage of their convictions, and he is left to sail for Tahiti alone. Basquiat loses all his friends because they cannot really understand the mind of this genius. They reject him when he fails to live by bourgeois rules; such as holding down a job, being faithful or arriving on time for appointments.

\section{Oviri and Basquiat}

In developing the Modern/Postmodern, heroic artist, one element that both films cover is the issue of race and the art world. Gauguin is beyond the petty, colonial attitude toward "others" - on the one hand, he defends the honor of his half-Javanese model/mistress against a bunch of ruffians, on the other, he is enmeshed in the European male's objectification and exploitation of the open sexuality of the exotic, non-European woman. ${ }^{17}$ Basquiat is delineated as someone who the art world saw as an "exotic" because of his blackness, and they both admired him and despised him for it. In one restaurant scene, for example, a group of middle-aged white businessmen stare and snicker at Basquiat; he pays for their meal. Therefore, the artist is someone who is not bound by the prejudices and injustices of the society from which he emerges.

16. It is not only films that promote this view. Hoban's chronicle of Basquiat is subtitled "A Quick Killing in Art," which clearly perpetuates the idea that Basquiat was destroyed by the avarice and disregard of in Basquiat's circle of friends, associates, and dealers (both art and otherwise).

17. Ambroise Vollard probably introduced this woman, Annah le Javanaise, to Gauguin. In December of 1893, she became Gauguin's model and mistress. This arrangement lasted until her return from Pont-Aven in the fall of 1894; moreover, every major text and this film on Gauguin retells the story of Gauguin versus the sailors and stevedores of Pont-Aven, defending the honor of his little Annah. See Cachin, Gauguin, 9798. 
In this way the artist transcends time to become a universal being with whom anyone could relate.

Artists disregard, moreover, the hypocritical sexual mores of mainstream, heterosexual society. Gauguin cannot be tied to one woman; Basquiat must follow his impulses in this regard as well. Henning does not acknowledge that Gauguin's sexual promiscuity was very damaging to women: even after finding out he had syphilis, Gauguin continued to pursue young women and to do nothing to prevent their contraction of the disease. ${ }^{18}$ Schnabel, too, has selective memory of the events and effects of Basquiat's sexual being because Schnabel does not tell the whole story. ${ }^{19}$ Basquiat had a number of relationships with both women and men and he carried on simultaneous, multiple relationships. Schnabel presents a conglomerate character for Basquiat's girlfriend; Schnabel then provides Courtney Love in a cameo as a one-night stand to intimate Basquiat's promiscuity. Nowhere within the film do we hear about the many people he infected with gonorrhea or the multiple times he did so. ${ }^{20}$

In order to preserve, perhaps, the tragic element of the life of Basquiat, the film Basquiat fails to focus on how excessive drug use in many senses destroyed Basquiat, the man. Perhaps Schnabel as writer and director felt this was too simple an answer and one that was too cliched to deserve notice. Thus, in several instances, Schnabel prefers to water down or ignore characteristics of Basquiat that some may find unappealing; perhaps he does this to heighten the viewer's sense of sadness at Basquiat's demise by making the viewer believe Basquiat to have been a "victim of circumstance" and of the craven attitudes of his dealers and collectors. Schnabel carries this hagiography of Basquiat to its conclusion in the culminating scene of the film. Basquiat wanders aimlessly -in his pajamas-along the streets of New York City as an almost operatic aria by John Cage swells behind our fallen hero. Then, he "surfs" from the car of his friend, Al Diaz (played by Benicio Del Toro), looking like the Statue of Liberty and jammin' to the Postmodernly hip Pogues. Shortly after this episode, authoritative text reveals that Basquiat died at age twenty-seven from a heroin overdose. Hence, the implication of this scene is not that Basquiat has lost, not only his friends, but also his mind, but rather that external forces killed him.

18. Eisenman, Nineteenth Century Art, 1997.

19. Schnabel narrates a moving tale of the solitary genius, the tragicomic pierrot or operatic clown thereby creating the romance in the words of David Bielejac, "artists as unique individuals who feel more deeply and have a burning, inner need to communicated spiritual truths [. . .]" and by transmitting this idea "[...] he effectively promoted his heroically scaled paintings as valuable handmade objects." See David Bjelajac, American Art: A Cultural History (Upper Saddle River, NJ: Prentice Hall, 2000), 386.

20. Hoban, Basquiat, 1997. 


\section{Legal Eagles and I Shot Andy Warhol}

Filmmakers' treatment of female characters is much less kind and infinitely less hagiographic. For instance, Chelsea Dearden-a completely fictional character-is rather one-dimensional. Instead of her artistic talent, it is her sexual allure that is played up within the narrative because she seduces one of the two main characters, Tom Logan, played by Robert Redford. Even her art emphasizes her sexual being: Dearden performs using over-lifesize photographs of herself, fire, and her own body writhing on the floor. Her art emanates from trauma and pain, because one can equate her physical actions as obsessively recreating the central trauma of her life: the death of her father from a fire in their studio/living quarters when Dearden was eight years old. Although the film is, ostensibly, about art, artists and the New York art scene of the mideighties, no one in the film is very interested in Dearden's art. Even though Dearden performs for Redford, they never substantively discuss the performance. Moreover, the galleries they visit are populated with works of Modern "masters": Picasso, Miro, Mondrian, and Dearden's father who plays a major part in the film although he is absent physically. One sees Victor (Dearden's father) from the back in flashback scenes, or so far away that his visage is obscured. Ironic, too, is the fact that his art is spoken about, but it is invisible: glimpsed only from the back where only the stretcher is in view. His work is ranked among the Modernist masters; whereas, Dearden's Postmodern performance is denigrated within the film. Hannah's Chelsea Dearden states about the one Postmodernist work that is even remarked upon, "Victor hated the Bertolini, he thought it was ridiculous...".

The subsidiary, yet ubiquitous, characters of I Shot Andy Warhol are as one-dimensional as those of Legal Eagles; artists at The Factory are presented as aesthetes and spoiled children in I Shot Andy Warhol. At the Factory people work on their art, yet they do not appear to have or even need to earn money. Money is not discussed, except in a very abstract way. This is contrasted with the many scenes of Solanas' hustling, prostituting, selling her words on the streets to whomever will pay. This mercantilism extends from and binds Solanas and Warhol. Warhol incessantly seeks out journalists, wealthy aristocrats and publicity. In one scene, he strolls around his studio discussing how everything must look a certain way for the press coming to interview him. Although Solanas is neither an aesthete, nor a spoiled child, she is complicit in this commodification of art and the art world. Her daily struggles to survive and to sell her work (soul?), moreover, imply that the "true" artist makes no distinction between art and the "real" world; therefore, every action of the artist-including violence-is an act of art.

When filmmakers choose to focus on women artists, the sexual politics of the films dictate that, instead of innate genius, female artists derive their creativity from insanity, or at least a fragile mental stability. This stands in stark contrast 
to male artists whose genius does not derive from imbalance; these artists are simply misunderstood by a philistine social environment. In Frida, for instance, Frida Kahlo is displayed in the last few hours of her life as a woman out of her mind, seeing only the past and her immanent death. Likewise, I Shot Andy Warhol explores Solanas' insanity, hyper-sensitivity and/or unhinging creativity. Thus, this film refuses to indulge in Modernist pronouncements of "truth" (in the sense of overall impression of the era, or in keeping with the "historical conditions") commonly seen as a criterion for historical films. ${ }^{21}$ At points, for instance when Valerie is panhandling or soliciting, she seems perfectly sane; in fact, perhaps the only sane person in her environment. At other times; specifically, when she is engaged in the production of her art, the SCUM Manifesto, she appears aggressive and unhinged. In other words, it is creating that imbalances Solanas, not society's incomprehension of the nature of creative genius. Finally, the director, Mary Harron, intercuts, in typical Postmodern collage, black-and-white scenes in which Valerie "explains" herself, using the words of the manifesto. ${ }^{22}$ In one particularly disturbing sequence, one sees Solanas creating her manifesto, followed by a black and white scene of her reading it which the cuts directly to a scene of a man shoving money into Solanas' mouth and then screwing her up against a brick wall. While one can view the overall sequence as theatrical and flattering to the character of Solanas by focusing exclusively on her as she works tirelessly on her manifesto, one can also say that these scenes appear like police line-ups with the criminal standing-alone and spotlighted-in a drab and indistinct interior. The blankness of the wall, therefore, contrasts with the raving of the character to create a sense that the character is off-balance, too animated.

Whereas the artists in Oviri and Basquiat are bound by their connections to "woman as muse," in Legal Eagles and I Shot Andy Warhol the issue of character cannot be divorced from that of sexual politics. In examining films about artists in general, it is clear that there is a strongly gendered reading by filmmakers that breaks down both in the titles and in the overall presentation of the artist. In addition to the disconcerting resort to insanity as creative font of women, even when a film is professedly about a sane woman, the plot often centers on an important male figure. I Shot Andy Warhol is presented ostensibly as a first-person narrative; however, there is little connection between the "I" of the title and the character of Solanas herself, in that the discourse is generally "told" in the third-person. The character of Warhol is given as much screen

21. Dudley Andrew, "Film and History," in Film Studies: Critical Approaches, ed. John Hill and Pamela Church Gibson (Oxford and NY: Oxford University, 2000), 174-187; Davis, Slaves on Screen, 9-15, 127-136, 138-140, and 157-160; Rosenstone, Visions, 201-205; Maria Wyke, Projecting the Past: Ancient Rome, Cinema, and History (NY: Routledge: 1997).

22. A copy of this manifesto can be found on the internet at Tom Jennings, Valerie Solanas' Scum Manifesto, posted January 1994, accessed 17 May 2020, https://bit.ly/3d99PVT 
time as the figure of Solanas. The first scene, for example, is one of Warhol's twitching legs. Subsequently, Solanas accosts a police officer to declare, "I shot Andy Warhol." The implication is that Solanas gains celebrity not for her accomplishments, but for her act of violence toward a well-known male artist. The film concludes in the same way, bringing the viewer full circle and diminishing Solanas' agency.

Warhol in this film is as much of a focus as is Solanas and this is not unusual in films that ostensibly treat women artists; for example, in Camille Claudel and Artemisia, August Rodin, Orazio Gentileschi and Agostino Tassi, respectively, play major roles; the creativity and artistic accomplishments of the women, on the other hand, are seen as products of the training the men have provided. Warhol is also the only person with whom, on some level, Solanas feels a connection. In the pivotal Factory party scene, Warhol and Solanas form a sort of island among the insensate beings lying about. This connection is illusory, however, because Warhol exploits, betrays and tacitly condones others' ridiculing of Solanas. Within this context it is clear why Solanas shoots Warhol. Simultaneously, by this point the film reverses its implicit critique of Warhol's treatment of Solanas, because the violence manipulates the viewer to identify with Warhol. Solanas is presented in the end as completely insane, believing her publisher has inserted an electronic tracking or controlling device into her uterus. The film, therefore, reads at the end as the biography of one woman's fall into insanity. The ending texts also inform us that Solanas died in a welfare hotel; when "cured" of her malaise, she became unproductive, destitute not only of goods, but also of creativity. She is thus unmasked as ordinary, not extraordinary and average, not genius.

In Oviri, women are little more than another object Gauguin uses to create his art. His Danish wife, Mette, who no longer serves his art, is displayed as severe, grasping and mercantile. She sells his paintings and hounds him for money, not because she is a woman trying to raise five children with little support from their father, but because she is a symbol of the bourgeoisie that can only appreciate the utility of art, not its beauty. Furthermore, Gauguin's half-Javanese model, whom he takes as a lover soon after her arrival at his studio, eventually desecrates one of his paintings and steals his money. The innocence of his landlord's daughter-who also provides some voiceover narrative-entices Gauguin to consider staying, but staying means being imprisoned in the petty values of mainstream French society. Moreover, in Oviri, the women have no names, while all the men are named, even minor and fleeting characters.

In Basquiat, too, women have little place beyond serving the ego of the artist. Gina, Basquiat's girlfriend, is long-suffering and indistinctly limned. During the time of the film she is transformed from an attractive, seemingly well-adjusted waitress/painter to a vamp in some scenes and a skeletal (perhaps drug-addled) shadowy background figure in others. Just as Basquiat is embroiled in his fall 
from grace-symbolized by the dark, black and rancid looking spots that appear on his face-he invites "Gina," (a character who is an amalgam of the plethora of Basquiat's girlfriends) now his ex-girlfriend, to eat in a chic restaurant. She is once again young and fresh looking and, apparently, happy. However, what emerges from their conversation is that the lesson she took from her relationship with Basquiat is that she is not a "true" painter. Thus, Basquiat is limned as the isolated genius, while "Gina" is just ordinary and only truly happy when she can be useful to the men in her environment: she is working for René Ricard and will attend law school the following term.

An extremely important element of the metanarratives of filmic texts on artists is their approach to the material. Although none of the films under discussion is a period drama or epic, it may be said that almost all of these films encourage a reading of them as some sort of historical document: presenting a vision of an artist or art environment in or of the past. ${ }^{23} \mathrm{~A}$ major ramification of treating these films as "historical documents" without being concerned much with history, is the willful omission of the complexities of the historical periods the filmmakers examine. A powerful example of this occurs in the contrast between the actual, diverse segment of avant-garde elements present in late nineteenth century French culture and how Oviri (re)presents this period as haute bourgeois and stifling on the one hand and bohemian in the extreme on the other. ${ }^{24}$ By setting up a strict polarization of the two, society is the misfit, not the artist.

A second element of the metanarratives is their critique of the motives of the art-buying public, as well as the stereotypes they bring to their purchase of art. For Basquiat, at least according to Schnabel, eighties consumerism was a powerful force. Even though people are willing to pay fabulous sums for Basquiat's work, made available through commercial networks such as the Annina Nosei Gallery, New York society does not understand Basquiat, the man. ${ }^{25}$ Basquiat becomes, therefore, as much a product as his works; his image-wild, unkempt, and "exotic" interests the art buying public as do his works. In reality, it cannot be said that buyers and artists were merely carried away with "hype"'; rather, they were knowledgeable and had been engaged in art criticism since, at least, World War II. The New York City art scene; particularly relating to postmodern artists, had been growing exponentially since World War II. Galleries handling twentieth century artists went from ninety to 290 in the years between 1949 and 1977. In 1984-85, the height of

23. Andrew, "Film and History," 174-187; Robert Rosenstone, Revisioning History: Film and the Construction of a New Past (Princeton: Princeton University Press, 1995); Rosenstone, Visions, 1996.

24. Eisenman, Gauguin's Skirt, 1994; Milner, Studios of Paris, 1990 examine the myriad art movements, avant-garde trends, and societal upheavals of late nineteenth century Paris.

25. Hoban, Basquiat, 114, 127-28, and 157. 
Basquiat's popularity, 1900 one-person exhibitions were held in New York City alone. Additionally, over one million people were identifying themselves as artists on the 1980 Census; on the 1990 Census 1.7 million self-identified as artists. The patrons for art were also evolving. From 1940 to 1980 there was a sixty-seven percent increase in corporation funding of new museums. ${ }^{26}$ Similarly, the discourses of Legal Eagle and I Shot Andy Warhol explicate the notion that the art world of the $80 \mathrm{~s}$ is crass and materialistic, while the artist is someone who is sensitive and must be protected from the crass materialism of the art scene as a whole. The filmmakers stress this concept repeatedly: parties abound where people wander aimlessly, seemingly more interested in other people than the art; each room of the galleries is filled with Modernist masterpieces, yet the work is never spoken of, it just exists as icons of the taste of the characters and of their rarefied world. The art world of the 60s, likewise, is superficial and populated by fawning dilettantes as the many scenes of the Factory, restaurants and bars of I Shot Andy Warhol make clear.

\section{Conclusions}

Finally, in attempting to understand these films, it is crucial to address the Modern/Postmodern divide (if there are truly points of identifiable split). In their individual narrative discourses, these four films, when compared and contrasted, do divulge Modernist and Postmodernist ideas about art and artists. ${ }^{27}$ In this context it can, perhaps, be said that while a Modernist believes in absolute truth, a Postmodernist is sure there is no such thing. If a Modernist can "trust the process" to convey the meaning, the Postmodernist disregards process and prioritizes content. ${ }^{28}$ If the Modernist believes in masters, the Postmodernist believes in the pluralism of experience of the art object. Lastly, if the Modernist knows that art has its own value, the Postmodernist is sure that context is art's value.

The emphasis on the "misunderstood master" of Oviri and the tragic hero of Basquiat display the artist in a Modernist manner. The focus on the commerce of art and Postmodern forms of performance art in Legal Eagles appear Postmodern in conception. However, the multivalency of Basquiat and the constant display of modern masters in Legal Eagles belie their artist presentations. This adds a level of discomfort and ambiguity for the viewer that the

26. Bjelajac, American Art, 330.

27. John Hill, "Film and Postmodernism," in Film Studies: Critical Approaches, ed. John Hill and Pamela Church Gibson (Oxford and NY: Oxford University, 2000), 94-103.

28. Bjelajac, American Art, 2000; Cachin, Gauguin, 1992; Crepaldi, Gauguin, 1999; Collings, It Hurts, 1998; Eisenman, Gauguin's Skirt, 1997; John Rewald, Studies in PostImpressionism (New York: Harry N. Abrams, 1986). 
straightforward Modernist Oviri does not: is Basquiat Modern or Postmodern? Given that the film is only four years old and the milieu of the film - the excessive, über-Postmodern, cynical, satirical, ironic mélange of 80s New York - one expects the film to have a more Postmodern thematic and theoretical underpinning than a standard tale of a genius done in by the forces of evil and his own ego (all grist of the Modernist mill). Legal Eagles, too, is essentially Modern in that it is the art of Dearden's Modernist father that is really lauded in the film, although the viewer never actually sees his paintings. Dearden's art is known largely in absentia, except for the scene enumerated above. That scene appears more mocking than serious, thus decimating respect for Postmodern aesthetic forms. I Shot Andy Warhol is the only truly and consistently Postmodern of the four films in its steadfast refusal to allow the viewer to identify one unbroken truth about art, the art world, Valerie Solanas and life itself. In an authentic Postmodernist vein, I Shot Andy Warhol is engorged with irony, or the satiric stance. The culmination of Solanas' ruminations in an act of violence as art is the supremely ironic element of the film, for destruction and creation are rarely linked so explicitly.

In terms of American culture at the beginning of a new millennium, this essay demonstrates that filmmakers are attempting to create an image of the perfect artist. That artist is male, genius, suffering (but not from insanity) and supremely misunderstood. The trope "artist" does not acknowledge the possibility of adding successful and well-balanced individuals the canon of "Greats." For all of these reasons, it is unlikely that Hollywood will anytime soon create the biopic "Georgia of the Desert." It is because of this inability to allow for a diversity of images of artists that the American viewing public will continue to believe a number of stereotypes the ramifications of which are immense. Some Americans may believe that one does not have to promote and support art programs; nor does one need to feed starving artists. The reasoning, inferred from the themes and characterizations in Hollywood films, would be that artistic ability is innate and cannot be augmented through education. Concomitantly, one does not have to feed a starving artist because it is the nature of the artist to be starving, it is suffering, instability, addiction and abuse that reveal the celluloid artist as worthy of the title "Artist."

\section{Bibliography}

Anderson, Carolyn, and Jonathon Lup. "Off-Hollywood Lives: Irony and Its Discontents in the Contemporary Biopic." Journal of Popular Film and Television 36, no. 2 (Summer 2008): 102-112.

Andrew, Dudley. "Film and History." In Film Studies: Critical Approaches, edited by John Hill and Pamela Church Gibson, 174-187. Oxford and NY: Oxford University, 2000.

Basquiat, Jean-Michel. Basquiat. Milan: Charta, 1999. 
Basquiat. Dir. Julien Schnabel. Perf. Jeffrey Wright and David Bowie. Miramax, 1996.

Beck, Bernard. "Real Genius: Pollock and Portraits of Artists in Movies." Multicultural Perspectives 3, no. 4 (2001): 11 -14.

Berger, Doris. Projected Art History: Biopics, Celebrity Culture, and the Popularizing of American Art. NY and London: Bloomsbury, 2014.

Billson, Anne. "The Art of Film: Galleries in the Movies." The Telegraph. Posted January 9, 2015. Accessed May 23, 2020. https://goo.gl/NYi31M.

Bjelajac, David. American Art: A Cultural History. Upper Saddle River, NJ: Prentice Hall, 2000.

Bordwell, David and Noël Carroll, eds. Post-theory: Reconstructing Film Studies. Madison, WI: University of Wisconsin, 1996.

Bovey, David. "The Artist Biopic: A Historical Analysis of Narrative Cinema, 1934-2010." PhD. diss., University of Westminster, 2015.

Brunette, Peter. "Post-structuralism and Deconstruction." In Film Studies: Critical Approaches, edited by John Hill and Pamela Church Gibson, 89-93. Oxford and NY: Oxford University, 2000.

Cachin, Françoise. Gauguin: The Quest for Paradise. NY: Harry N. Abrams, 1992.

Crepaldi, Gabriele. Gauguin: A Restless and Visionary Genius-His Life in Paintings. NY: Dorling Kindersley, 1999.

Collings, Matthew. It Hurts: New York Art from Warhol to Now. London: 21 Publishing, 1998.

Dalle Vacche, Angela._Cinema and Painting: How Art is Used in Film. Austin: University of Texas Press, 1996.

D'Alleva, Anne. Look! Again: Art History and Critical Theory. Upper Saddle River, NJ: Pearson, 2005.

Davis, Natalie Zemon. Slaves on Screen. Cambridge, MA: Harvard University, 2000.

Dyer, Richard. "Introduction to Film Studies." In Film Studies: Critical Approaches, edited by John Hill and Pamela Church Gibson, 1-8. Oxford and NY: Oxford University, 2000.

Eisenman, Stephen. Gauguin's Skirt. London: Thames and Hudson, 1997.

Gaylord, Jim. "10 Things Hollywood Teaches Us About the Art World." Art in the Movies. Posted December 24, 2014. Accessed May 23, 2020. https://goo.gl/XzKPfX.

Gocsik, Karen, Dave Monahan, and Richard Barsam. Writing About Movies. Fifth edition. NY: W.W. Norton \& Company, 2019.

Grasso, Laura R. "Misery, Then Tragedy: The Rise and Fall of an Artist's Myth in Relationship to the Culture Industry." Master's Thesis, Sotheby's Institute of Art, 2015.

Harris, Jonathan. The New Art History: A Critical Introduction. London and NY: Routledge, 2001.

Hill, John. "Film and Postmodernism." In Film Studies: Critical Approaches, edited by John Hill and Pamela Church Gibson, 94-103. Oxford and NY: Oxford University, 2000.

Hoban, Phoebe. Basquiat: A Quick Killing in Art. NY: Penguin, 1997.

I Shot Andy Warhol. Dir. Mary Harron. Perf. Lili Taylor and Jared Harris. Samuel Goldwyn Company, 1996.

Jacobs, Steven. Framing Pictures: Film and the Visual Arts. Edinburgh: Edinburgh University Press, 2011.

. "Strange Exhibitions: Museums and Art Galleries in Film." In Strange Spaces: Explorations into Mediated Obscurity, edited by André Jansson, and Amanda Lagerkvist, 297-316. Burlington, VT: Ashgate, 2009. 
Jennings, Tom. Valerie Solanas' Scum Manifesto. January 1994. Accessed 17 May 2020. https:// bit.ly/3d99PVT.

Legal Eagles. Dir. Ivan Reitman. Perf. Robert Redford, Debra Winger, and Daryl Hannah. Universal City Studios, 1986.

Leach, Jim. "A Matter of Life and Art: Artist Biopics in Post-Thatcher Britain." In Rule, Britannia! The Biopic and British National Identity, edited by Homer B. Pettey, and R. Barton Palmer, 163-181. Albany: State University of New York Press, 2018.

Marshall, Richard, Robert Farris Thompson, Rene Ricard, Klaus Kertess, Greg Tate, and Dick Hebdige. Jean-Michel Basquiat. NY: Abrams, 1995.

Mayer, Rivka D. "Transformations of Cinematic Signifiers of the Myth of Genius." Master's Thesis, University of Liverpool, 2001.

Metz, Christian. The Imaginary Signifier: Psychoanalysis and the Cinema. Bloomington, IN: Indiana University Press, 1986.

Milner, John. The Studios of Paris: The Capitol of Art in the Late Nineteenth Century. New Haven and London: Yale University Press, 1990.

Mulvey, Laura. Visual and Other Pleasures (Theories of Representation and Difference). Bloomington, IN: Indiana gsUniversity Press, 1989.

Naifeh, Steven, and Gregory White Smith. Jackson Pollock: An American Saga. Aiken, SC: Woodward/White Publishing Company, 1998.

Name, Billy. All Tomorrow's Parties: Billy Name's Photographs of Andy Warhol's Factory. NY: Powerhouse Cultural Entertainment, 1997.

O’Brien, Glenn. Basquiat. NY: Tony Shafrazi Gallery, 1999.

Oviri. Dir. Carlsen Henning. Perf. Donald Sutherland. CBS/Fox, 1986.

Plagens, Peter. “Biopics Mix Shticks, Kitsch.” ARTnews 105, issue 11 (December 2006): 118121.

Polaschek, Bronwyn. The Postfeminist Artist Biopic. London: Palgrave Macmillan, 2013.

Rewald, John. Studies in Post-Impressionism. New York: Harry N. Abrams, 1986.

Rosenstone, Robert. Revisioning History: Film and the Construction of a New Past. Princeton: Princeton University Press, 1995.

. Visions of the Past: The Challenge of Film to Our Idea of History. Cambridge, MA: Harvard University Press, 1996.

Vidal, Belen. "Feminist Historiographies and the Woman Artist's Biopic: The Case of Artemisia." Oxford Journal 48, no. 1 (2007): 69-90.

Wyke, Maria. Projecting the Past: Ancient Rome, Cinema, and History. NY: Routledge: 1997. 
